Document downloaded from:

http://hdl.handle.net/10251/147998

This paper must be cited as:

Temino-Boes, R.; Romero Gil, I.; Paches Giner, MAV.; Martínez-Guijarro, MR.; RomeroLopez, R. (2019). Anthropogenic impact on nitrification dynamics in coastal waters of the Mediterranean Sea. Marine Pollution Bulletin. 145:14-22.

https://doi.org/10.1016/j.marpolbul.2019.05.013

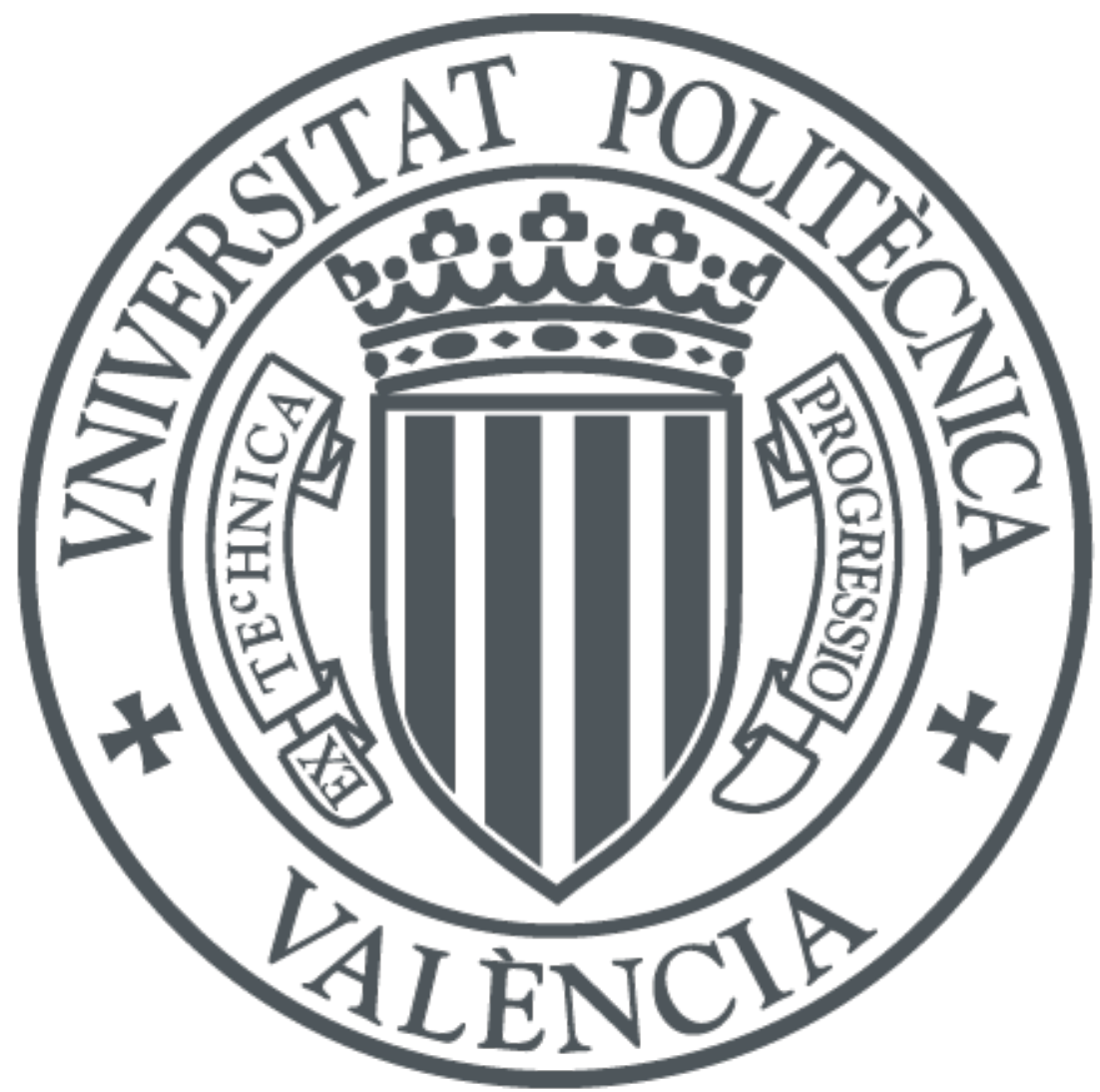

The final publication is available at

https://doi.org/10.1016/j.marpolbul.2019.05.013

Copyright Elsevier

Additional Information 


\section{Anthropogenic impact on nitrification dynamics in coastal waters of the Mediterranean Sea}

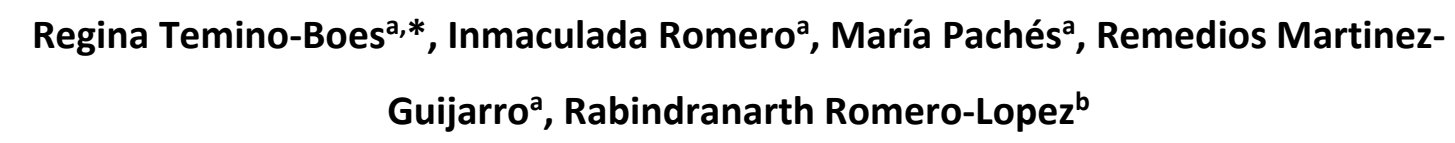

a. Instituto de Ingeniería del Agua y del Medio Ambiente, Universitat Politècnica de València, Camino de Vera s/n, Valencia 46022, Spain

b. Departamento de Ingeniería Civil, Universidad Veracruzana, Lomas del Estadio s/n, Xalapa 91000, Mexico

* Corresponding author

\section{Abstract}

The anthropogenic alteration of the nitrogen cycle results in the modification of the whole food web. And yet, the impact caused on nitrogen dynamics in marine systems is still very uncertain. We propose a workflow to evaluate changes to coastal nitrification by modelling nitrite dynamics, the intermediary compound. Nitrite concentrations were estimated with a simple steady state nitrification model, which was calibrated in 9 NW Mediterranean coastal sites with different anthropogenic pressures, located within $250 \mathrm{~km}$. The results obtained indicate that nitrite peaks are observed in winter and explained by nitrification response to temperature, but these dynamics are altered in impacted coastal waters. We found the second step of nitrification to be more sensitive to temperature, which entails a significant impact of climate change on the decoupling of the two steps of nitrification. The results could be extrapolated to numerous coastal regions of the Mediterranean Sea with similar characteristics.

\section{Keywords}

Nitrification dynamics, Coastal waters, Mediterranean Sea, Anthropogenic impact, Nitrogen cycle, Inorganic Nitrogen Speciation

\section{Introduction}

Rockström et al. (2009) established the alteration of the nitrogen (N) cycle as one of the three planetary processes, together with climate change and biodiversity loss, sufficiently 
altered by human activity as to potentially have disastrous consequences for humans. Some authors are concerned about nitrogen being "the next carbon" (Battye et al., 2017). Due to their vulnerability to anthropogenically driven change, coastal zones have been highly impacted (Arhonditsis et al., 2000; De Vittor et al., 2016; Smith et al., 2014). Population growth and related nutrient sources such as agriculture, wastewater, urban runoff, and fossil fuels have increased nutrient inputs to coastal waters to many times their natural levels (Bricker et al., 2008). As such, many researchers have evidenced the impact that human activities have caused to food webs or biogeochemical processes in many coastal systems (Borja et al., 2004; Lundberg et al., 2005; Wang et al., 1999). In the Mediterranean Sea, direct wastewater discharges account for a large amount of the total nitrogen input (Powley et al., 2016; Stamou and Kamizoulis, 2008). Nearshore coastal waters (0-200 m) are particularly vulnerable and need a special attention, as the nutrient gradient from land to ocean is considerably large in the Mediterranean Sea (Flo et al., 2011).

Nitrification plays a crucial role in marine primary production (Yool et al., 2007) and in the $\mathrm{N}$ cycle of coastal zones (Damashek et al., 2016; McLaughlin et al., 2017). This process alone does not change the total amount of nitrogen in an ecosystem, but it affects its speciation and fate: nitrate (the product of nitrification) serves as substrate for denitrification, which removes $\mathrm{N}$ from the system via $\mathrm{N}_{2}$ gas (Carini et al., 2010). Nitrification is generally described as a twostep process occurring under aerobic conditions: oxidation of ammonium to nitrite and oxidation of nitrite to nitrate (Kim, 2016). It links reduced and oxidized forms of nitrogen. Although ammonium oxidation is considered the limiting step, both steps are expected to be tightly coupled. However, evidence of decoupling in coastal waters was observed especially at high temperatures (Beman et al., 2013; Heiss and Fulweiler, 2016), which leads to the accumulation of nitrite. As an intermediary compound in many key biological processes, nitrite dynamics have historically been used as an indicator of the balance between oxidative and reductive pathways in marine systems (Lomas and Lipschultz, 2006). Nitrite production processes in aerobic waters include the oxidation of ammonia and assimilatory nitrate reduction by phytoplankton and heterotrophic bacteria, while removal pathways for nitrite include oxidation by nitrite-oxidizing bacteria and phytoplankton uptake (Schaefer and Hollibaugh, 2017).

Increasing evidence indicates that many environmental factors such as $\mathrm{pH}$, temperature or oxygen concentration affect nitrification processes (Damashek et al., 2016; Schaefer and Hollibaugh, 2017). However, when it comes to how humans alter inorganic nitrogen transformations in marine environments research is still very scarce. Kim (2016) summarized 
how climate change will alter marine $\mathrm{N}$ cycle and indicated the need for further research on marine inorganic N transformations, while McLaughlin et al (2017) and Bartl et al. (2018) studied the alteration of nitrification caused by wastewater discharges and pointed out the need for further research on anthropogenic nutrient effect on coastal biogeochemistry. Ocean acidification results in reduced nitrification rates (Beman et al., 2010; Huesemann et al., 2002; Kitidis et al., 2011) while other anthropogenic pressures such as $\mathrm{N}$ deposition (Kim, 2016) or wastewater effluents might increase nitrification (McLaughlin et al., 2017). Clearly, the overall anthropogenic effect on nitrification in coastal systems needs to be evaluated further. In the Mediterranean Sea, the urbanization on the littoral zone has severely impacted the natural balance of ecosystems (Lejeusne et al., 2010). Nitrification dynamics are altered in those areas with high anthropogenic pressure, leading to a change in nitrogen cycling along the year (Ordines et al., 2015). The modification of such an important process in the $\mathrm{N}$ cycle may have consequences on phytoplankton abundance and diversity, with cascading effects on other organisms. The importance of nitrification in the $\mathrm{N}$ biogeochemistry in coastal waters has already been proved by many authors (Damashek et al., 2016; Heiss and Fulweiler, 2016; Huesemann et al., 2002), but the mechanisms by which anthropogenic activity alters nitrification in coastal waters need to be studied in more detail.

The aim of this study was to propose a simple workflow for the evaluation of nitrification alteration in coastal waters due to anthropogenic activity. Nitrite, as the intermediary compound in the two steps of nitrification, was used to study nitrification. We modelled nitrite dynamics in several coastal sites located within approximately $250 \mathrm{~km}$ of coast. All modelled water bodies have similar characteristics but different anthropogenic pressures, so that nitrification parameters could be related to anthropogenic pressure. This methodology is applicable to other coastal areas of the Mediterranean Sea, where nitrification is the main driver of nitrite dynamics (Bianchi et al., 1994).

\section{Materials and methods}

\subsection{Study area and analytical methods}

The Jucar River Basin District (JRBD) lies in the Mediterranean coast of Spain, covering $42,735 \mathrm{~km}^{2}$ with $574 \mathrm{~km}$ of coastline. The management plan defines 16 natural coastal water bodies. In this study we focused on 9 of them, which belong to the typology II-A (moderately influenced by freshwater inputs with salinity between 34.5 and $\left.37.5 \mathrm{~g} \mathrm{~kg}^{-1}\right)$. These water bodies (presented in Figure 1) have similar geomorphology, littoral transport, dominant winds, rainfall, area of fluvial basins, continental inputs and wet zones. C002 is the reference site for 
97 typology II-A with no relevant anthropogenic influence, as determined by Romero et al. (2013)

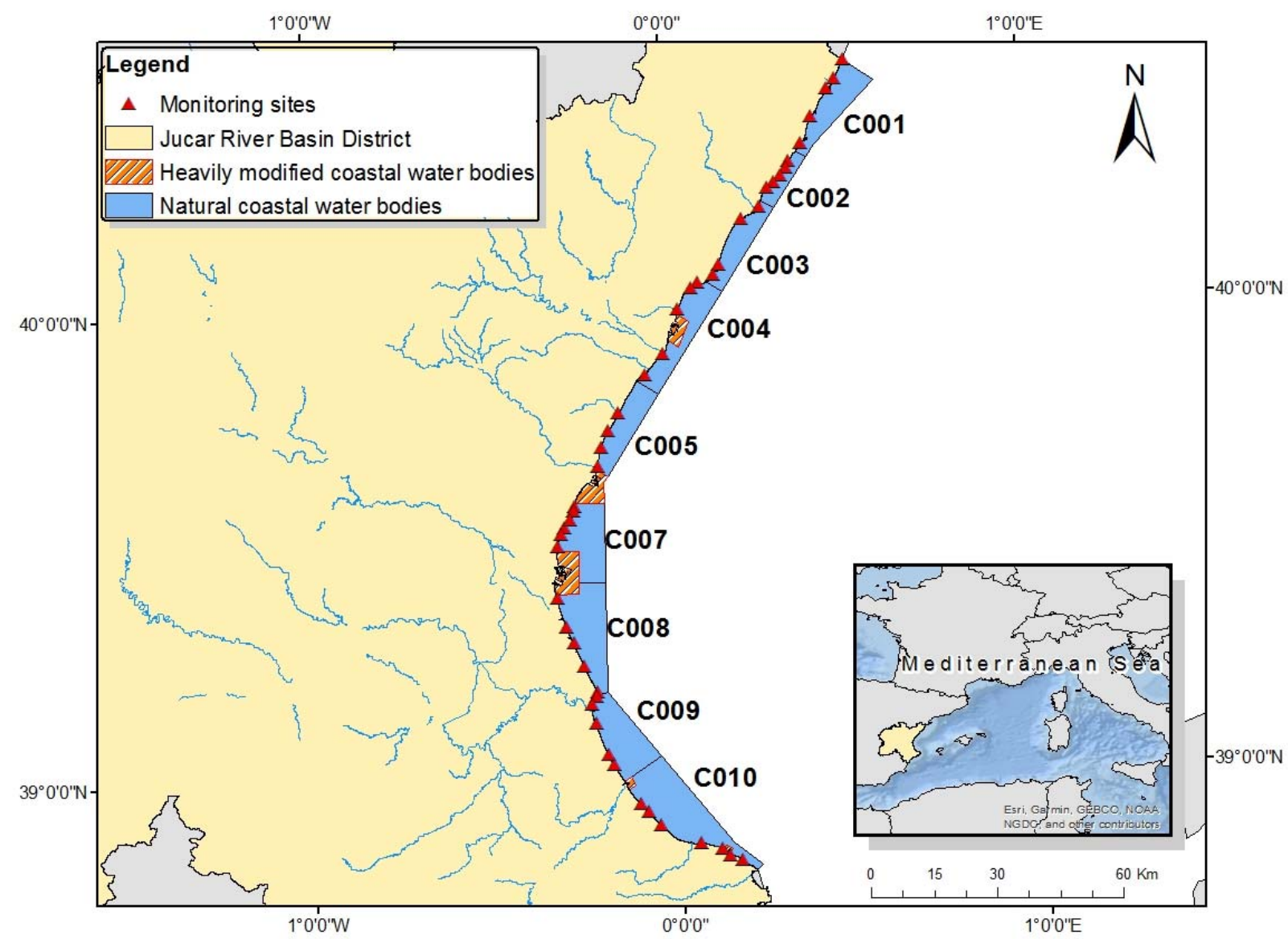
and Pachés et al. (2012) who evaluated pressures and impacts according to annex $V$ of the Water Framework Directive (WFD). Some coastal waters in the JRBD are considered under the WFD as heavily modified due to the presence of a harbor (Figure 1); these water bodies were not included in our study.
103 
inshore sampling was more convenient. 46 monitoring sites were distributed all along the coast, with 4 to 7 stations in each water body. Each month from August 2008 until January 2011, water samples were taken from beyond the wave breakpoint at a $10 \mathrm{~cm}$ depth. Temperature was measured in situ with a multiparametric probe YSI (6600 V2).

Water samples were collected in plastic bottles, refrigerated, and carried to the laboratory within 12 hours. A Portasal 8410 A salinometer was calibrated to determine salinity (I.A.P.S.O. Standard Seawater, Ocean Scientific International Ltd., K15 = 0.99986, S = 34.995\%o). Samples were divided into several sets following the conservation procedures suggested by APHA (2005) and filtered through $0.45 \mu \mathrm{m}$ cellulose acetate membrane filters (Millipore HAWP). These membranes are stored at $-20^{\circ} \mathrm{C}$ in order to break the cells for chlorophyll-a analysis.

For the determination of chlorophyll-a, the trichromatic method was used, based on visible spectroscopy (APHA, 2005). The filters are introduced in $6 \mathrm{ml}$ of $90 \%$ acetone in water with 1\% calcium carbonate. The optical density of the extract was determined at different wavelengths $(630,647$ and $664 \mathrm{~nm})$ to determine the pigment content, and at $750 \mathrm{~nm}$ to determine the optical density not due to chlorophyll-a. The equations proposed by Jeffrey and Humprey (1975) were used for concentration calculations. The detection limit was $0.2 \mathrm{mgC} . \mathrm{m}-3$ of chlorophyll-a.

Nutrients (ammonium, nitrite and nitrate) were analyzed with an Alliance Instruments Integral Futura air-segmented continuous-flow autoanalyzer, following the procedure described by Treguer and Le Corre (1975) and taking into account the remarks made by Kirkwood et al. (1991) and Parsons et al. (1984). The equipment optimization is carried out following Coakley (1981) theories. Ammonium and nitrite were analyzed with the filtered samples, right after filtration, while the samples kept for nitrate determination were frozen for a later analysis. Ammonium was measured based on Berthelot's reaction. Under alkaline conditions, ammonium reacts with the hypochlorite forming a monochloramine. This compound, in the presence of phenol and an excess of hypochlorite, forms indophenol blue. The nitroprusside ion catalyzes the reaction and trisodium citrate eliminates the interference of Ca and Mg (Solòrzano, 1969). Nitrite concentrations were determined with Shinn (1941) water analysis method, adapted for seawater by Bendschneider and Robinson (1952). This method is based on the reaction of nitrite ion with sulfanilamide in acidic conditions, producing a diazo compound that forms a pink complex with $\mathrm{N}$-naphthylethylene diamine. For the determination of nitrate concentrations, this compound is reduced to nitrite by means of a $\mathrm{Cu} / \mathrm{Cd}$ reducing column in basic conditions $(\mathrm{pH}=8.5)$, following the method described by (Grasshoff, 1976). Subsequently, nitrite is analyzed by the procedure described above. High 
The proposed workflow is schematized in Figure 2 and explained in detail in next sections.

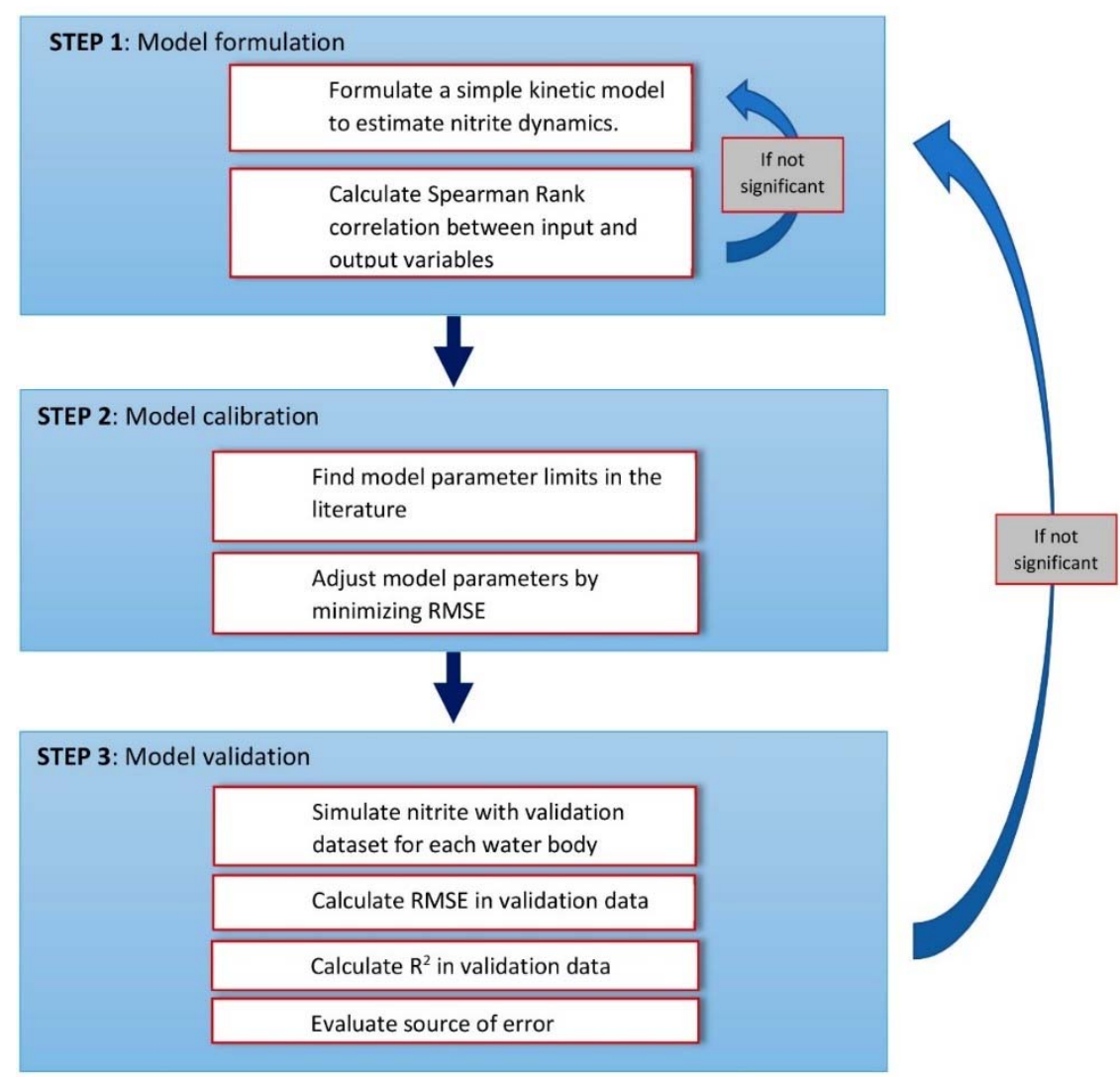

Figure 2. Descriptive diagram of the research workflow

\subsubsection{Model formulation}

The equation solved is based on the principle of the conservation of mass. The main processes driving nitrite dynamics were studied from the literature and used for the development of the model, neglecting the less relevant processes. We applied a mass balance in zero dimensions in each water body which was considered as a control volume. As samples 
were taken at the surface, we considered appropriate to neglect the effect of the sediment. Simple and well-known principles can be used to build simple models which can give an overall understanding of nitrogen processes. When a basic understanding of the system is aimed and the requirement to the precision of estimated values is low, simple models perform better (Højberg et al., 2007). Complex models require large amounts of data and such a model would not add value to our research purpose.

Nitrite production pathways in coastal waters include ammonia oxidation and assimilatory nitrate reduction by phytoplankton and heterotrophic bacteria, while removal pathways for nitrite include nitrite oxidation and phytoplankton uptake (Schaefer and Hollibaugh, 2017). Ammonium is the preferred form of nitrogen for phytoplankton uptake (Chau and Jin, 1998; Zouiten et al., 2013), so we considered direct nitrite uptake to be negligible. Additionally, the study area is characterized by low phytoplankton concentrations in natural conditions (Pachés et al., 2012). Thus, nitrite release by phytoplankton was also neglected. An analysis of the relationship between the model error and phytoplankton concentrations was carried out to confirm this assumption (see section 2.2.2). Bianchi et al. (1994) also determined that nitrite concentrations in the NW Mediterranean Sea are regulated by the two steps of nitrification. Therefore, we considered only nitrification processes to estimate nitrite: formed with ammonium oxidation (nitrification first step) and eliminated by nitrite oxidation (nitrification second step). Studies carried out in other coastal areas also pointed out the significant role of nitrification (Damashek et al., 2016; Schaefer and Hollibaugh, 2017).

At low nitrogen concentrations as those found in natural systems, the process of nitrification is generally represented by a first order kinetic reaction (Bowie et al., 1985). Previous studies typically considered only the temperature effect on nitrification. Some authors also introduced the effect of dissolved oxygen as a limiting factor (Chau and Jin, 1998; Umgiesser et al., 2003; Zouiten et al., 2013). Nonetheless, the samples used in this study, which were taken at the sea surface, had all high oxygen concentrations (averaged $8.3 \pm 1.4 \mathrm{mgO} . \mathrm{L}^{-1}$ measured during campaigns). Consequently, we did not add oxygen limitation to our model. $\mathrm{pH}$, which also affects nitrification rates (Park et al., 2007), was measured during the campaigns and variations were not relevant (averaged $8.14 \pm 0.13$ ).

Flo et al. (2011) showed that continental influence is the main driver of nutrient variability within $200 \mathrm{~m}$ of coast in the NW Mediterranean Sea. The water bodies considered in this study have a length of $>13 \mathrm{~km}$ along the coast, and samples were taken at less than $50 \mathrm{~m}$ from the coastline. As such, the continental influence on nutrient concentrations is much larger than the 
effect of the dispersion along the coast. Additionally, as the two steps of nitrification are tightly coupled (Schaefer and Hollibaugh, 2017), nitrite is oxidized to nitrate almost as fast as it is created (see Table 1), whereas longitudinal mixing along $>13 \mathrm{~km}$ is expected to be a much slower process (Stamou and Kamizoulis, 2008). Therefore, we decided not to consider dispersion with adjacent water bodies to simplify our model.

The main nitrogen sources to the JRBD coastal waters are agriculture and urban population (Romero et al., 2013), which means that most of the nitrogen inputs are in the form of ammonium or nitrate. Hence, we considered no relevant direct nitrite inputs. An analysis of the relationship between the model error and salinity was carried out to confirm this assumption (see section 2.2.2).

Equation 1 represents nitrite mass balance under these assumptions.

$$
\frac{\partial\left[\mathrm{NO}_{2}^{-}\right]}{\partial t}=k_{1} \theta_{1}{ }^{T-20}\left[\mathrm{NH}_{4}{ }^{+}\right]-k_{2}{\theta_{2}}^{T-20}\left[\mathrm{NO}_{2}{ }^{-}\right]
$$

Where, $\left[\mathrm{NO}_{2}{ }^{-}\right]$is nitrite concentration $\left(\mathrm{mgN.L}^{-1}\right),\left[\mathrm{NH}_{4}{ }^{+}\right]$is ammonium concentration (mgN.L' $\left.{ }^{1}\right)$, $t$ is time (day), $k_{1}$ is ammonium oxidation rate at $20^{\circ} \mathrm{C}\left(\right.$ day $\left.^{-1}\right), \theta_{1}$ is temperature coefficient for ammonium oxidation, $\mathrm{k}_{2}$ is nitrite oxidation rate at $20^{\circ} \mathrm{C}\left(\mathrm{day}^{-1}\right), \theta_{2}$ is temperature coefficient for nitrite oxidation, $\mathrm{T}$ is temperature $\left({ }^{\circ} \mathrm{C}\right)$.

The steady state approach is very frequently used in water quality modelling (Chapra, 1997; Wang et al., 2013). This approach enables the calculation of the nitrite concentration each month, if the conditions found at the time of the sampling were maintained. Under this assumption the accumulation term was set to zero. Nitrite concentrations can be estimated with the following equation, derived from Equation 1:

$$
\left[N O_{2}^{-}\right]=\left(\frac{k_{1}}{k_{2}}\right)\left(\frac{\theta_{1}}{\theta_{2}}\right)^{T-20}\left[{N H_{4}^{+}}^{+}\right]
$$

$K_{1}$ and $K_{2}$ depend mathematically on each other (see $K_{1}$ and $K_{2}$ depend mathematically on each other (see Equation 2), making the separate calibration of both parameters unfeasible. The same applied to $\Theta_{1}$ and $\theta_{2}$. We defined $K$ and $\theta$ as new parameters equivalent to the ratios $\mathrm{k}_{1} / \mathrm{k}_{2}$ and $\Theta_{1} / \Theta_{2}$ respectively:

$$
\left[\mathrm{NO}_{2}{ }^{-}\right]=K \cdot \theta^{T-20}\left[\mathrm{NH}_{4}^{+}\right]
$$

Equation 3

$$
\text { Thus, } \mathrm{K} \text { represents the ratio of ammonium oxidation to nitrite oxidation, while } \Theta \text { represents }
$$
the ratio of ammonium to nitrite oxidation sensitivity to temperature. 

coefficient in nonlinear but monotonic relationships (Pianosi et al., 2016). As such, the Spearman correlation coefficient was calculated between selected input (temperature and ammonium) and output variables to determine the relative importance in nitrite estimation. The calculation of this correlation confirms whether the selected input variables are relevant for the estimation of nitrite concentrations, or else the simplified model needs to be reevaluated.

\subsubsection{Model calibration and validation}

We carried out a literature review to set parameter limits. The values found are presented in Table 1.

Table 1

232 Bibliographical parameter values

\begin{tabular}{ccc}
\hline Parameter & Range & Unit \\
\hline $\mathrm{K}_{1}$ & $0.05-0.5$ & $\mathrm{~d}^{-1}$ \\
$\mathrm{~K}_{2}$ & $0.5-10$ & $\mathrm{~d}^{-1}$ \\
$\Theta_{1}$ & $1.02-1.12$ & - \\
$\theta_{2}$ & $1.02-1.12$ & -
\end{tabular}

References: (Bowie et al., 1985; Chau and Jin, 1998; Myszograj, 2015; Zouiten et al., 2013) to January 2011. The dataset was divided in two sub-datasets; one was used as calibration data and the second as validation data. Odd monthly observations $(1,3,4 \ldots, 29)$ of input and output variables were used for calibration whereas even observations $(2,4,6, \ldots, 30)$ were left for validation (see Figure 2). The parameters $K$ and $\theta$ were optimized to reproduce nitrite observed concentrations by minimizing the rooted mean squared error (RMSE) in calibration data. Then, the model was run with the validation dataset and nitrite estimations were compared to observations. The RMSE and the coefficient of determination $\left(R^{2}\right)$ were calculated

242 to estimate the goodness of fit.

243 Two of the neglected processes during the model formulation may be the main source of error to our model: phytoplankton release and continental inputs. To evaluate the source of error in the model, we calculated Spearman correlation between monthly error and phytoplankton and between monthly error and salinity in each water body. 
248 Once the model was validated, the relationship between model parameter differences 249 among water bodies and two physicochemical variables was evaluated to determine the 250 source of spatial changes in nitrification dynamics. $\mathrm{pH}$ and dissolved oxygen were very similar 251 in all water bodies as mentioned above and consequently not included in this evaluation. The two physical variables analyzed were temperature and salinity. The Spearman correlation coefficient between these two variables and calibrated model parameters was calculated to determine whether they may influence the studied nitrification parameter values.

Phytoplankton biomass is established as an indicator of the ecological status of coastal waters under the WFD. In the JRBD, Pachés et al. (2012) identified chlorophyll-a $50^{\text {th }}$ percentile to be the most appropriate statistical parameter to measure anthropogenic pressure, and Romero et al. (2013) related phytoplankton to anthropogenic pressures such as population density, agriculture and industry. As such, we used chlorophyll-a $50^{\text {th }}$ percentile as an indicator of the alteration provoked by human pressures. We calculated the Spearman correlation coefficient between model parameters and chlorophyll-a $50^{\text {th }}$ percentile to determine whether anthropogenic pressures may have altered nitrification parameters.

\section{Results}

\subsection{Variable values}

Ammonium, nitrite and nitrate concentrations in each water body are presented in Figure 3 , as well as temperature, salinity and chlorophyll-a. The highest $\mathrm{N}$ concentrations were found in C007, the water body located north of Valencia city. Chlorophyll-a was also high in C007; the most polluted site of the JRBD (Pachés et al., 2012; Temino-Boes et al., 2018). C002, the reference water body, had low $\mathrm{N}$ concentrations, together with $\mathrm{C001}$ and $\mathrm{C003}$. The lowest

270 salinities were found in $\mathrm{C005}$ and C007, with some low salinity events in C009. The latest water

271 body corresponds to the discharge of the Jucar river. Temperature is slightly lower in sites C001

272 to $\mathrm{C003.}$ 

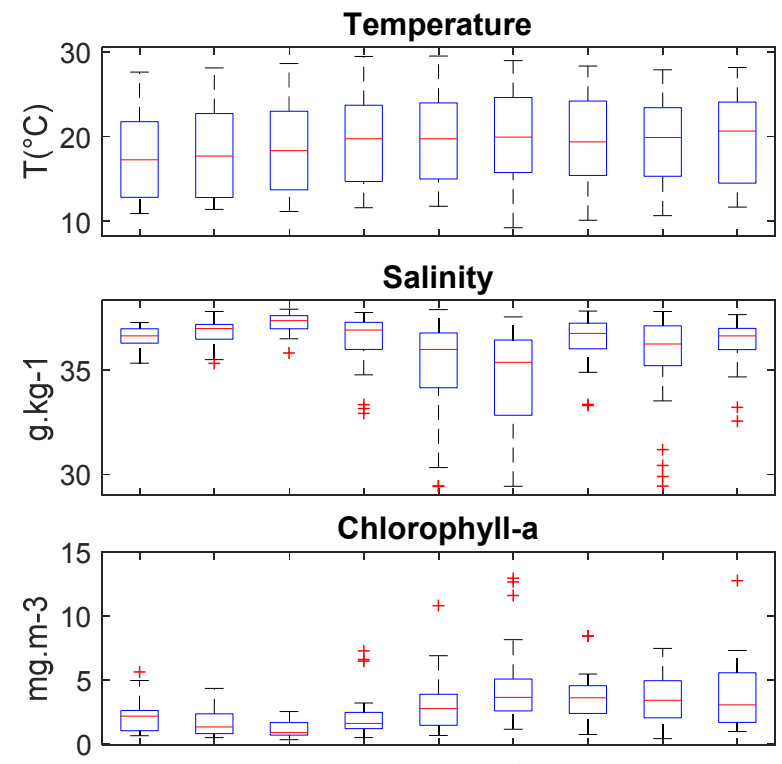

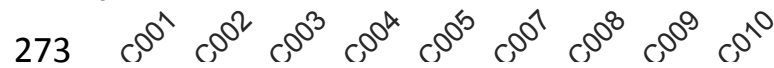

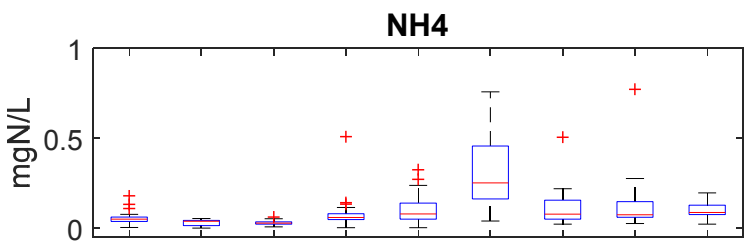

NO2

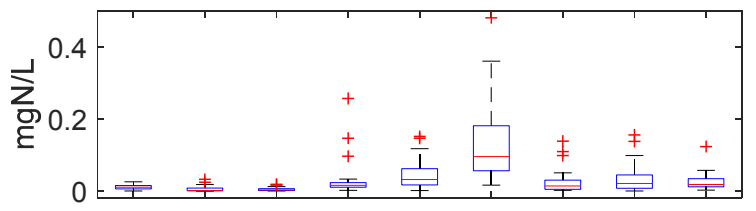

NO3

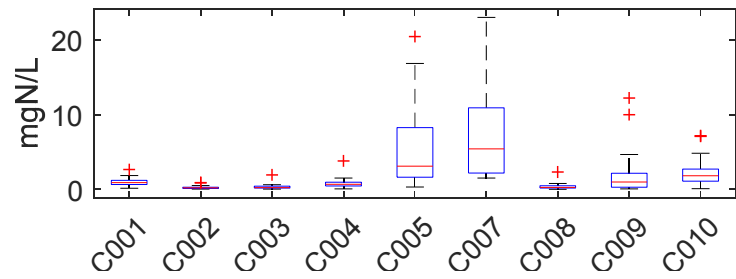

274 Figure 3. Boxplot of ammonium, nitrite and nitrate concentrations of all water bodies from

275 August 2008 to January 2011. Each data point corresponds to the mean concentration of all

276 monitoring sites of a water body for a given time. Some outliers were also observed in C007 in

$277 \quad N$ concentrations which do not appear in the figure due to the limits of the $y$-axis.

278

279

280

281

282

283

284

285

286

287

288

289

\subsection{Model results}

Spearman correlation between model forcings (water temperature and ammonium) and output variable (nitrite concentration) was calculated to determine which variable had the highest influence on nitrite concentrations in each water body. We found a significant rank correlation between nitrite and temperature in all water bodies except C005 and C007 (Table 2) which correspond to the sites with highest continental influence (see salinity in Figure 3). On the other hand, ammonium was significantly correlated to nitrite in all water bodies except C002 to C004. These sites correspond to the lowest observed inorganic nitrogen concentrations and chlorophyll-a (Figure 3).

\section{Table 2}

Spearman rank correlation between output variable (nitrite) and input variables (temperature and ammonium)

\begin{tabular}{ccc}
\hline Water Body & $\mathbf{T}\left({ }^{\circ} \mathrm{C}\right)$ & $\mathbf{N H}_{4}\left(\mathbf{m g N} . \mathrm{L}^{-1}\right)$ \\
\hline $\mathrm{C} 001$ & $-0.38^{*}$ & $0.49^{*}$ \\
$\mathrm{C} 002$ & $-0.67^{*}$ & 0.28 \\
$\mathrm{C} 003$ & $-0.55^{*}$ & 0.30 \\
$\mathrm{C} 004$ & $-0.61^{*}$ & 0.44
\end{tabular}




$\begin{array}{lcl}\text { C005 } & -0.36 & 0.56 * \\ \text { C007 } & 0.08 & 0.79 * \\ \text { C008 } & -0.60^{*} & 0.85 * \\ \text { C009 } & -0.44^{*} & 0.57 * \\ \text { C010 } & -0.37 * & 0.52 *\end{array}$

$290 *$ Significant correlations at the $95 \%$ confidence level ( $p$-value $<0.05$ )

291 We calibrated and validated the model for each water body, and the obtained results are

292 presented in Figure 4. The parameters $\mathrm{K}$ and $\Theta$ obtained for each water body are shown in

293 Table 3. We calculated the RMSE and $\mathrm{R}^{2}$ in validation data (Table 3). Ammonium oxidation rate

294 is often estimated as an order of magnitude lower than nitrite oxidation for surface water

295 quality modelling as shown in Table 1. This observation agrees with our findings which

296 established a K mean value of 0.17 (Table 3).

297 In most water bodies $\Theta$ was below 1, which indicates that nitrite oxidation is more sensitive 298 to temperature changes than ammonium. Under this circumstance, nitrite peaks are observed 299 in low temperature periods (December and January). The sites with the lowest anthropogenic 300 pressures (C002 and $\mathrm{CO03}$ ) show clear nitrite peaks in the mentioned period. Only two water 301 bodies (C007 and C008) presented a $\Theta$ higher than 1. 


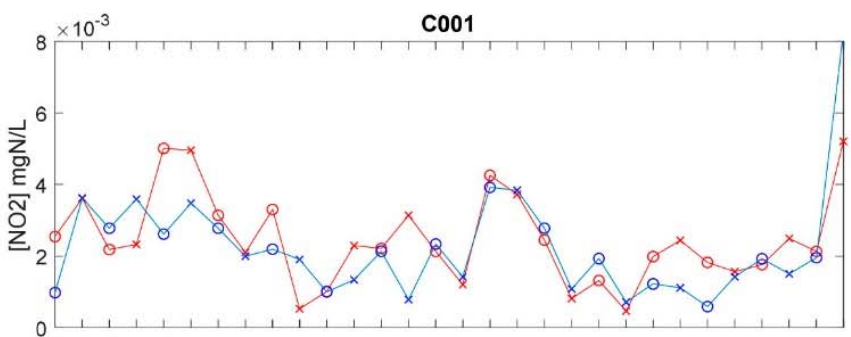

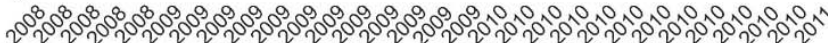

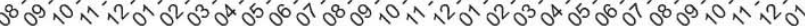

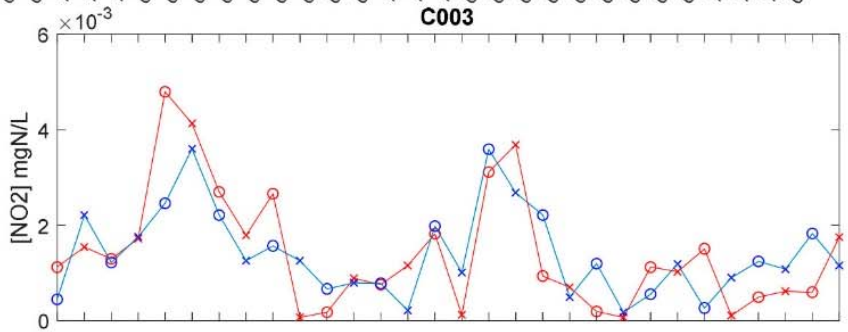

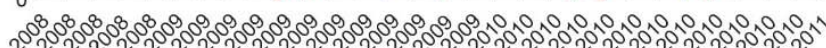

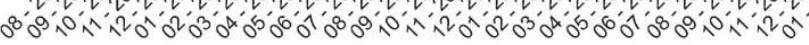

C005

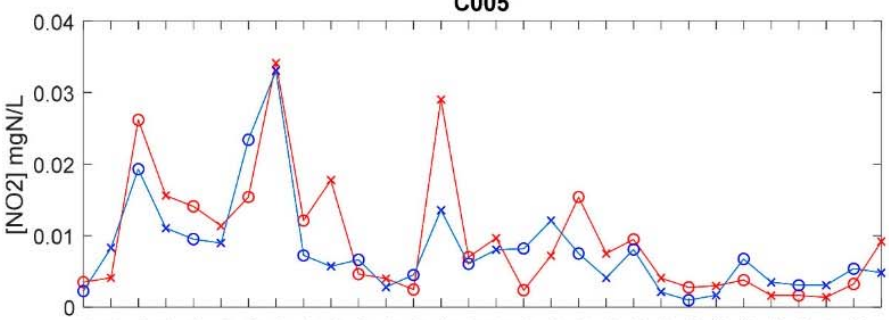

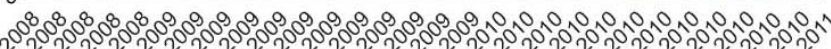

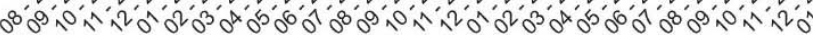

$\mathrm{COO8}$

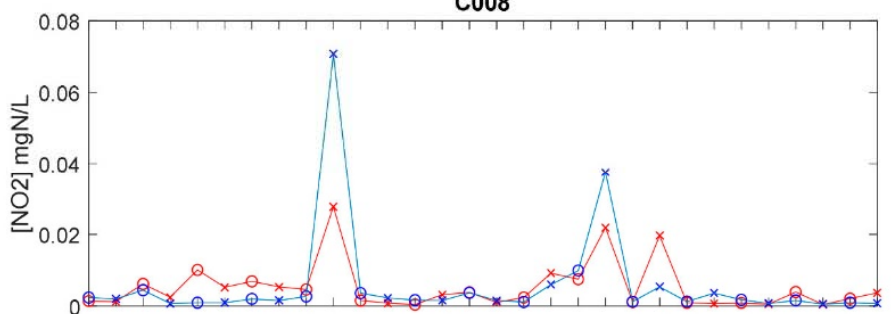

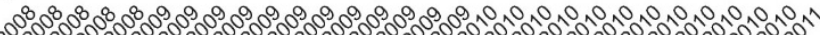

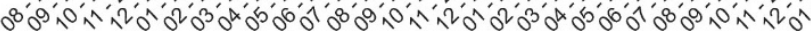

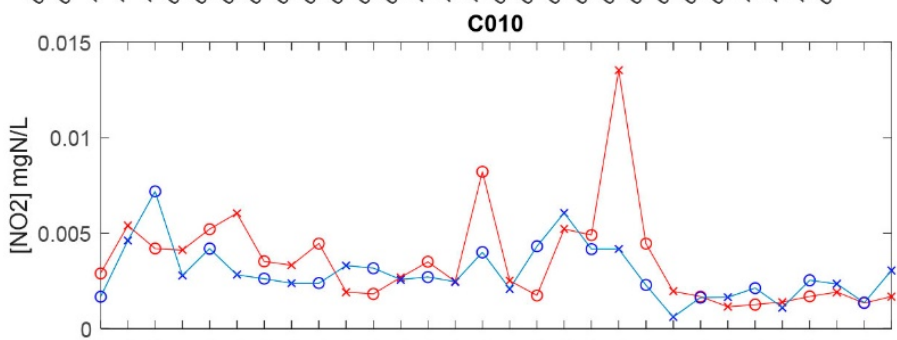

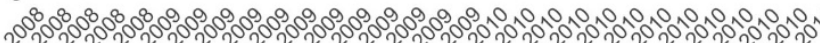

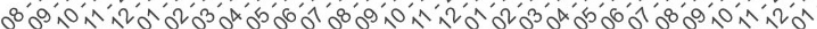

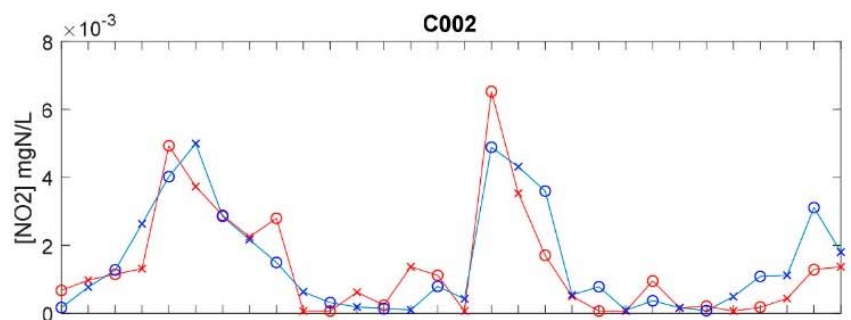

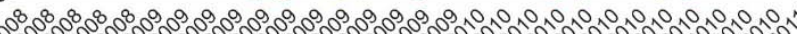

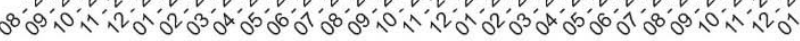

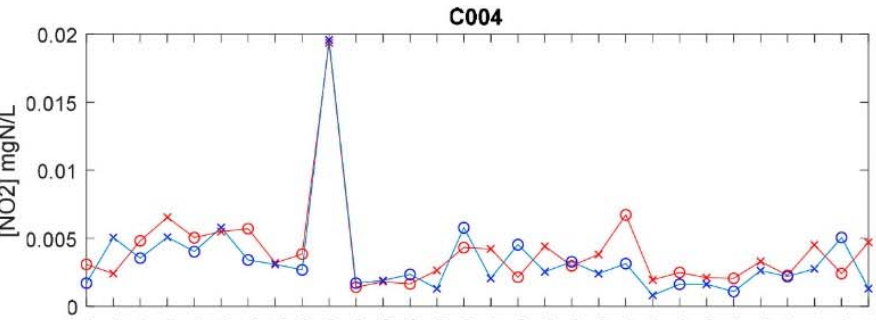

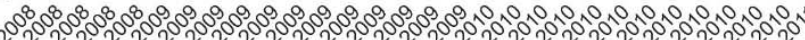

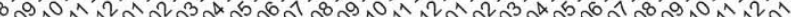

$\mathrm{COO7}$

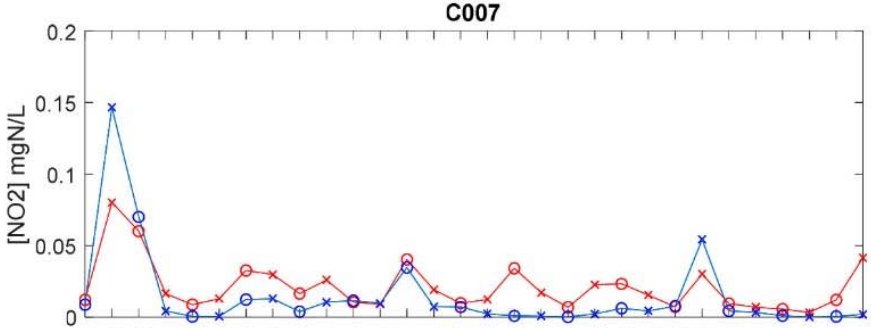

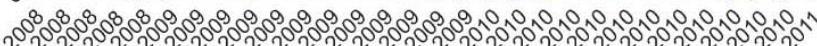

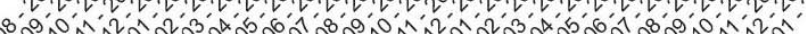

C009

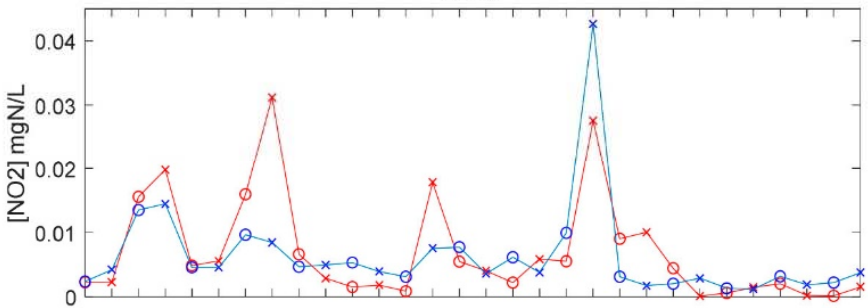

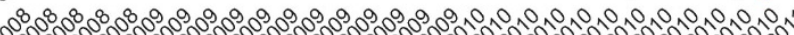

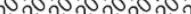

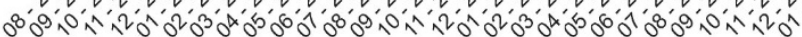

Figure 4. Mean nitrite measured (red line) and estimated (blue line) concentrations in all water 


\section{Table 4}

Spearman rank correlation between error with chlorophyll-a (Chl-a) and salinity (S)

\begin{tabular}{ccc}
\hline Water Body & S & Chl-a \\
\hline C001 & -0.27 & -0.06 \\
C002 & -0.26 & -0.11 \\
C003 & 0.15 & 0.01 \\
C004 & 0.34 & 0.29 \\
C005 & $0.52^{*}$ & -0.16 \\
C007 & 0.34 & 0.26 \\
C008 & 0.03 & -0.09 \\
C009 & $0.48^{*}$ & -0.22 \\
C010 & 0.33 & -0.05 \\
\hline
\end{tabular}



parameters and RMSE are calculated in Table 5. Both $\Theta$ and the RMSE have a high rank correlation with chlorophyll-a $50^{\text {th }}$ percentile, an indicator of the ecological status of coastal waters. Additionally, salinity is related to the RMSE.

Table 5

323 Spearman Rank Correlation of model parameters and root mean squared error (RMSE) with 324 mean salinity, mean temperature and chlorophyll-a 50th percentile.

\begin{tabular}{cccc}
\hline & Salinity $\left({\left.\mathrm{g} . \mathrm{kg}^{-1}\right)}^{-1}\right.$ & Temperature $\left.^{\circ} \mathrm{C}\right)$ & P50 Chlorophyll-a \\
\hline $\mathbf{K}$ & -0.41 & 0.45 & 0.02 \\
$\boldsymbol{\theta}$ & -0.42 & 0.50 & $0.80^{*}$ \\
RMSE & $-0.73^{*}$ & 0.42 & $0.97^{*}$
\end{tabular}

Note: Significant correlations at the $95 \%$ confidence level ( $p$-value $<0.05)$ are marked with an asterisk

327 Figure 5 shows how the parameter $\theta$, which represents the difference in temperature

328 influence between ammonium and nitrite oxidation, is influenced by anthropogenic activity.

329 Closer to big urban areas, like the city of Valencia in C007, $\Theta$ increases, while it decreases in $330 \mathrm{C002}$ or $\mathrm{C003}$ where the population is smaller. On the contrary, $\mathrm{K}$ does not have an

331 anthropogenic influence (Table 5). 


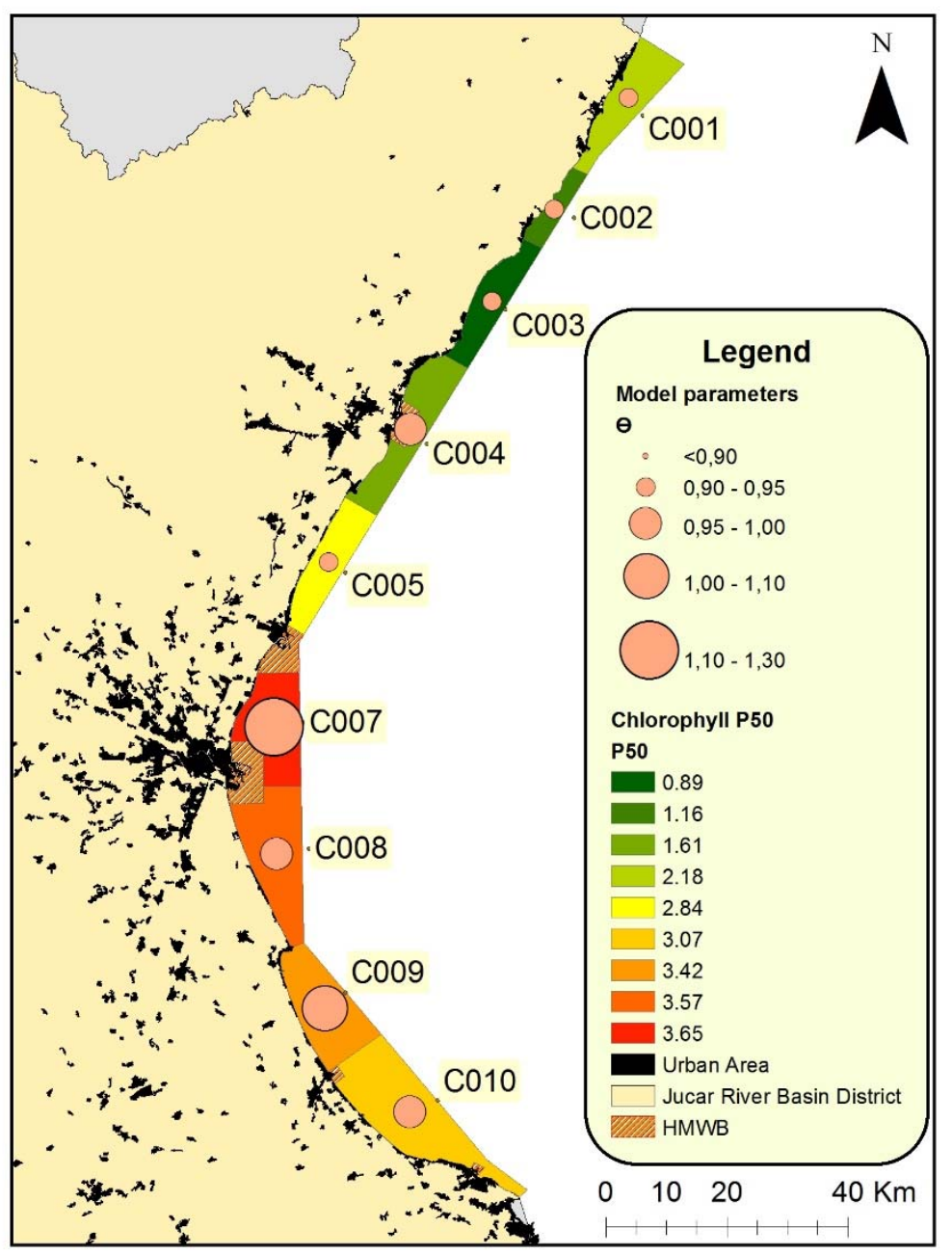

333 Figure 5. Model parameter $\Theta$ for each water body, $50^{\text {th }}$ percentile of chlorophyll-a, population and Heavily modified water bodies (HMWB) due to the presence of a harbour.

\section{Discussion}

The natural annual cycle of nitrite showed peaks in cold months (December and January), as found in the reference water body $\mathrm{COO2}$ (Figure 4). However, this cycle was highly perturbed in anthropogenically altered coastal zones, with peaks occurring both in cold and warm seasons driven by ammonium concentrations. Our results demonstrate that the two steps of nitrification are decoupled in coastal waters, agreeing with late findings (Heiss and Fulweiler, 2016; Schaefer and Hollibaugh, 2017). Different speeds in the two steps of nitrification were also observed in the Jucar estuary (Romero et al., 2007). In our model, peaks occur due to the different response to temperature in ammonium and nitrite oxidation (parameter $\theta$ ). Many previous studies found high nitrite concentrations at warmer seasons (Bristow et al., 2015; 
Heiss and Fulweiler, 2016; Schaefer and Hollibaugh, 2017) while others (such as this study) observed nitrite peaks at low temperatures (Pitcher et al., 2011).

The changes observed in nitrite dynamics among water bodies indicate a shift in nitrification temperature dependence parameter $\theta$ due to anthropogenic activity (Figure 5). Nitrification requires the mediation of a vast diversity of microorganisms, which makes it an essential process for marine life. Pachés et al. (2012) proved how anthropogenic activity is changing microorganism composition in coastal waters of the JRBD, which may explain the spatial differences found in ammonium and nitrite oxidation temperature parameters. Although no previous study considered this dependence in coastal waters, studies carried out in wastewater determined the dependence of nitrification temperature coefficient on microorganism composition and abundance (Myszograj, 2015). In addition, wastewater effluents alter the biogeochemical cycling and phytoplankton composition (Howard et al., 2017) which may have caused shifts in nitrification temperature dependence. Future research is required to describe the processes driving nitrification dependency on temperature. Previous studies identified a dependence of nitrification rates on salinity (Bernhard et al., 2007; Heiss and Fulweiler, 2016), and low salinity events with elevated concentrations of certain ammonium oxidizing archaea (Schaefer and Hollibaugh, 2017). Bernhard et al. (2005) indicated that the abundance and diversity of ammonium oxidizing bacteria is highly controlled by salinity, and Heiss and Fulweiler (2016) found lower nitrite oxidation rates with higher salinity events. Bianchi et al. (1999) linked high ammonium oxidizing rates with low salinity events in the NW Mediterranean Sea.

We found temperature to be an important driver of ammonium and nitrite oxidation decoupling under natural conditions, which entails climate change could have a great impact in this process. In the reference water body $\mathrm{C002}$, which represents unaltered nutrient concentrations, the value of $\Theta$ was lower than 1 . This result indicates that under pristine conditions the second step of nitrification (nitrite oxidation) is more sensitive to temperature than the first step. Climate change will therefore have a greater impact in this second step. In addition, some studies forecast an important precipitation loss in the Jucar area (Chirivella et al., 2016; Miró et al., 2018) which would considerably reduce the riverine inputs of ammonium and other forms of nitrogen. The decrease in ammonium concentrations would have a direct effect on the rate of nitrification. Therefore, it may be expected to have lower nitrite concentrations due to reduced nitrification rates and a shift in nitrite peaks due to higher temperatures. Further research is needed to evaluate how the combined effect of nitrogen pollution and climate change will modify the nitrification process in coastal waters. 

the accuracy of the model. The coefficient of determination $R^{2}$ is lower in C001, C009 and C010

381 (Table 3). As the number of stressors increases, the functioning of the ecosystem is altered, and the estimation of nutrient concentrations is hindered (O'Meara et al., 2017). High nitrite events no longer occur due to natural conditions but rather to an unusual increase in human inputs. Continental inputs are the main source of error to sites 0005 and 0009 as shown by the Spearman correlations between error and salinity (see Table 4). Those water bodies have higher continental influence as indicated by the low salinities. The Jucar river discharges in C009, which is most probably the source of nitrite during the peaks not reproduced by the model. High nitrite concentrations in $\mathrm{C010}$ also correspond to low salinity event indicating an external source of nitrite not simulated in our model. Although nitrite concentrations in C001 did not have a significant correlation with salinity, this water body is located close to the Ebro delta, which may influence nitrification dynamics in this water body. On the other hand, phytoplankton does not have a significant correlation with the error (Table 4) which indicates that neglecting phytoplankton uptake and release is not an important source of error to the model.

The proposed workflow is applicable to other coastal areas with samples taken at the surface to avoid the effect of dissolved oxygen limitation. $\mathrm{pH}$ variations along the year in the Mediterranean Sea are usually less than $\pm 0.1 \mathrm{pH}$ units (Flecha et al., 2015), and therefore $\mathrm{pH}$ is not expected to be one of the main drivers of nitrification. The effect of phytoplankton and external inputs are the most important processes to be considered before applying the model to other coastal areas. In the Mediterranean Sea, marine waters are often oligotrophic (Vollenweider et al., 1996) and phytoplankton release of nitrite is presumably negligible in most areas. The nitrification kinetic model proposed could be extended to add other processes in the application to other study sites. However, the steps proposed in the workflow of Figure 2 can be followed for the study of any areas if the model is adapted. Future studies are needed to evaluate the mechanisms by which nitrification dynamics are altered by human activity and which are its most relevant consequences.

\section{Conclusions}

Our results show how nitrification dynamics are perturbed in highly populated coastal zones. Under natural conditions nitrite peaks are observed in winter due to low temperatures, but 410 this tendency is completely altered in anthropogenically impacted water bodies. The change observed in the sensitivity to temperature of the two steps of nitrification was highly 
412 correlated to chlorophyll-a 50th percentile, a measure of the ecological status (Spearman

413 correlation $r=0.80$ ). Temperature was the main driver of monthly variation in natural

414 conditions, which indicates a potential effect of climate change on nitrification dynamics.

415 Nitrification is a fundamental process of nitrogen biogeochemistry. As a key nutrient, the

416 alteration of the nitrogen cycle may result in the change of the whole food web in marine

417 ecosystems. Further research concerning the human driven changes of the nitrogen cycle in

418 marine environments is essential to enable experts to propose recovery measures and avoid

419 reaching a point of no return.

\section{Acknowledgements}

421 Field data collection was supported by the Regional Ministry of the Environment, Water, Urban

422 Planning and Housing. The work was partly supported by Erasmus Mundus - MAYANET Grant

423 Agreement Number 2014-0872 / 001 - 001, funded with support from the European

424 Commission.

\section{References}

APHA, 2005. Standard Methods for the Examination of Water and Wastewater, 21th ed. American Public Health Association, American Water Works Association, Water Environment Federation, Washington D.C.

Arhonditsis, G., Tsirtsis, G., Angelidis, M.O., Karydis, M., 2000. Quantification of the effects of nonpoint nutrient sources to coastal marine eutrophication: applications to a semienclosed gulf in the Mediterranean Sea. Ecol. Modell. 129, 209-227. doi:10.1016/S03043800(00)00239-8

Bartl, I., Liskow, I., Schulz, K., Umlauf, L., Voss, M., 2018. River plume and bottom boundary layer - Hotspots for nitrification in a coastal bay? Estuar. Coast. Shelf Sci. 208, 70-82. doi:10.1016/J.ECSS.2018.04.023

Battye, W., Aneja, V.P., Schlesinger, W.H., 2017. Is nitrogen the next carbon? Earth's Futur. 5 , 894-904. doi:10.1002/2017EF000592

Beman, J.M., Chow, C.E., King, A.L., Feng, Y., Fuhrman, J.A., Andersson, A., Bates, N.R., Popp, B.N., Hutchins, D.A., 2010. Global declines in oceanic nitrification rates as a consequence of ocean acidification 108, 208-213. doi:10.1073/pnas.1011053108 
Beman, J.M., Leilei Shih, J., Popp, B.N., 2013. Nitrite oxidation in the upper water column and oxygen minimum zone of the eastern tropical North Pacific Ocean. ISME J. 7, 2192-2205. doi:10.1038/ismej.2013.96

Bendschneider, K., Robinson, R.J., 1952. A new spectrophotometric determination of nitrite in sea water. J. Mar. Res. 2, 87-96.

Bernhard, A.E., Donn, T., Giblin, A.E., Stahl, D.A., 2005. Loss of diversity of ammonia-oxidizing bacteria correlates with increasing salinity in an estuary system. Environ. Microbiol. 7, 1289-1297. doi:10.1111/j.1462-2920.2005.00808.x

Bernhard, A.E., Tucker, J., Giblin, A.E., Stahl, D.A., 2007. Functionally distinct communities of ammonia-oxidizing bacteria along an estuarine salinity gradient. Environ. Microbiol. 9, 1439-1447. doi:10.1111/j.1462-2920.2007.01260.x

Bianchi, M., Feliatra, Lefevre, D., 1999. Regulation of nitrification in the land-ocean contact area of the Rhône River plume (NW Mediterranean). Aquat. Microb. Ecol. 18, 301-312. doi:10.3354/ame018301

Bianchi, M., Morin, P., Le Corre, P., 1994. Nitrification rates, nitrite and nitrate distribution in the Almeria-Oran frontal systems (eastern Alboran Sea). J. Mar. Syst. 5, 327-342. doi:10.1016/0924-7963(94)90054-X

Borja, Á., Franco, J., Valencia, V., Bald, J., Muxika, I., Belzunce, M.J., Solaun, O., 2004. Implementation of the European water framework directive from the Basque country (northern Spain): a methodological approach. Mar. Pollut. Bull. 48, 209-218. doi:10.1016/j.marpolbul.2003.12.001

Bowie, G.L., Mills, W.B., Porcella, D.B., Campbell, C.L., Pagenkopf, J.R., Rupp, G.L., Johnson, K.M., Chan, P.W.H., Gherini, S.A., 1985. Rates, Constants, and Kinetics Formulations in Surface Water Quality Modeling (Second Edition). U.S. Environ. Prot. Agency.

Bricker, S.B., Longstaff, B., W., D., Jones, A., Boicourt, K., Wicks, C., Woerner, J., 2008. Effects of nutrient enrichment in the nation's estuaries: A decade of change. Harmful Algae 8, 2132.

Bristow, L.A., Sarode, N., Cartee, J., Caro-Quintero, A., Thamdrup, B., Stewart, F.J., 2015. Biogeochemical and metagenomic analysis of nitrite accumulation in the Gulf of Mexico 
471

Carini, S.A., McCarthy, M.J., Gardner, W.S., 2010. An isotope dilution method to measure nitrification rates in the northern Gulf of Mexico and other eutrophic waters. Cont. Shelf Res. 30, 1795-1801.

Chapra, S.C., 1997. Surface Water Quality Modelling. New York.

Chau, K.W., Jin, H., 1998. Eutrophication Model for a Coastal Bay in Hong Kong. J. Environ. Eng. 124, 628-638. doi:10.1061/(ASCE)0733-9372(1998)124:7(628)

Chirivella, V., Capilla, J.E., Pérez-Martín, M.A., 2016. Dynamical versus statistical downscaling for the generation of regional climate change scenarios at a Western Mediterranean basin: The Júcar River District. J. Water Clim. Chang. 7, 379-392. doi:10.2166/wcc.2015.207

Coakley, W.A., 1981. Handbook of automated analysis. Continuous flow techniques. Marcel Dekker, New York.

Damashek, J., Casciotti, K.L., Francis, C.A., 2016. Variable Nitrification Rates Across Environmental Gradients in Turbid, Nutrient-Rich Estuary Waters of San Francisco Bay. Estuaries and Coasts 39, 1050-1071. doi:10.1007/s12237-016-0071-7

De Vittor, C., Relitti, F., Kralj, M., Covelli, S., Emili, A., 2016. Oxygen, carbon, and nutrient exchanges at the sediment-water interface in the Mar Piccolo of Taranto (Ionian Sea, southern Italy). Environ. Sci. Pollut. Res. 23, 12566-12581. doi:10.1007/s11356-0154999-0

European Commission, 2000. Directive 2000/60/EC of the European Parliament and of the Council of 23 October 2000 establishing a framework for Community action in the field of water policy.

Flecha, S., Pérez, F.F., García-Lafuente, J., Sammartino, S., Ríos, A.F., Huertas, I.E., 2015. Trends of $\mathrm{pH}$ decrease in the Mediterranean Sea through high frequency observational data: indication of ocean acidification in the basin. J. Chem. Inf. Model. 53, 1689-1699. doi:10.10138/srep16770

Flo, E., Garcés, E., Manzanera, M., Camp, J., 2011. Coastal inshore waters in the NW Mediterranean: Physicochemical and biological characterization and management 
Grasshoff, K., 1976. Methods of seawater analysis. Verlag Chemie: Weinstein, New York.

501

502

503

504

505

506

507

508

509

510

511

512

513

514

515

Heiss, E.M., Fulweiler, R.W., 2016. Coastal water column ammonium and nitrite oxidation are decoupled in summer. Estuar. Coast. Shelf Sci. 178, 110-119. doi:10.1016/J.ECSS.2016.06.002

Hermosilla Gómez, Z., 2009. Desarrollo metodológico para la correcta evaluación del estado ecológico de las aguas costeras de la Comunidad Valenciana, en el ámbito de la Directiva Marco del Agua, utilizando la clorofila a como parámetro indicador de la calidad. Universitat Politècnica de València.

Højberg, A.L., Refsgaard, J.C., Van Geer, F., Jørgensen, L.F., Zsuffa, I., 2007. Use of Models to Support the Monitoring Requirements in the Water Framework Directive. Water Resour. Manag. 21, 1649-1672. doi:10.1007/s11269-006-9119-y

Howard, M.D.A., Kudela, R.M., McLaughlin, K., 2017. New insights into impacts of anthropogenic nutrients on urban ecosystem processes on the Southern California coastal shelf: Introduction and synthesis. Estuar. Coast. Shelf Sci. 186, 163-170. doi:10.1016/J.ECSS.2016.06.028

Huesemann, M.H., Skillman, A.D., Crecelius, E.A., 2002. The inhibition of marine nitrification by ocean disposal of carbon dioxide. Mar. Pollut. Bull. 44, 142-148. doi:10.1016/S0025326X(01)00194-1

Jeffrey, S.W., Humprey, G.F., 1975. New spectrophotometric equations for determining chlorophylls a, b, and c in higher plants, algae and natural phytoplankton. Biochem. und Physiol. der Pflanz. 167, 191-194.

Kim, H., 2016. Review of inorganic nitrogen transformations and effect of global climate change on inorganic nitrogen cycling in ocean ecosystems. Ocean Sci. J. 51, 159-167. doi:10.1007/s12601-016-0014-z

Kirkwood, D., Aminot, A., Pertillä, M., 1991. Report on the Results of the ICES Fourth Intercomparison Exercise for Nutrients in Sea Water. Cooperative Research Report No. 174, International Council for the Exploration of the Sea. Copenhagen.

Kitidis, V., Laverock, B., McNeill, L.C., Beesley, A., Cummings, D., Tait, K., Osborn, M.A., 
Widdicombe, S., 2011. Impact of ocean acidification on benthic and water column ammonia oxidation. Geophys. Res. Lett. 38, 2-6. doi:10.1029/2011GL049095

Lejeusne, C., Chevaldonné, P., Pergent-Martini, C., Boudouresque, C.F., Pérez, T., 2010. Climate change effects on a miniature ocean: the highly diverse, highly impacted Mediterranean Sea. Trends Ecol. Evol. 25, 250-260. doi:10.1016/j.tree.2009.10.009

Lomas, M.W., Lipschultz, F., 2006. Forming the primary nitrite maximum: Nitrifiers or phytoplankton? Limnol. Oceanogr. 51, 2453-2467. doi:10.4319/lo.2006.51.5.2453

Lundberg, C., Lönnroth, M., Von Numers, M., Bonsdorff, E., 2005. A multivariate assessment of coastal eutrophication. Examples from the Gulf of Finland, northern Baltic Sea. Mar. Pollut. Bull. 50, 1185-1196. doi:10.1016/j.marpolbul.2005.04.029

McLaughlin, K., Nezlin, N.P., Howard, M.D.A., Beck, C.D.A., Kudela, R.M., Mengel, M.J., Robertson, G.L., 2017. Rapid nitrification of wastewater ammonium near coastal ocean outfalls, Southern California, USA. Estuar. Coast. Shelf Sci. 186, 263-275. doi:10.1016/J.ECSS.2016.05.013

MedGIG, 2009. Water Framework Directive inercalibration technical report. Part 3: Coastal and Transitional waters.

Miró, J.J., Estrela, M.J., Caselles, V., Gómez, I., 2018. Spatial and temporal rainfall changes in the Júcar and Segura basins (1955-2016): Fine-scale trends. Int. J. Climatol. 38, 46994722. doi:10.1002/joc.5689

Myszograj, S., 2015. The Impact of Temperature on the Removal of Nitrogen Compounds in Activated Sludge System. Br. J. Appl. Sci. Technol. 11, 1-13. doi:10.9734/BJAST/2015/18950

O'Meara, T.A., Hillman, J.R., Thrush, S.F., 2017. Rising tides, cumulative impacts and cascading changes to estuarine ecosystem functions. Sci. Rep. 7, 1-7. doi:10.1038/s41598-01711058-7

Ordines, F., Farriols, M.T., Lleonart, J., Guijarro, B., Quetglas, A., Massutí, E., SCOULLOS, M., 2015. Biology and population dynamics of by-catch fish species of the bottom trawl fishery in the western Mediterranean, Mediterranean Marine Science. Hellenic Center for Marine Research. 
Pachés, M., Romero, I., Hermosilla, Z., Martinez-Guijarro, R., 2012. PHYMED: An ecological classification system for the Water Framework Directive based on phytoplankton community composition. Ecol. Indic. doi:10.1016/j.ecolind.2011.07.003

Park, S., Bae, W., Chung, J., Baek, S.C., 2007. Empirical model of the pH dependence of the maximum specific nitrification rate. Process Biochem. 42, 1671-1676. doi:10.1016/j.procbio.2007.09.010

Parsons, T.R., Maita, Y., Lalli, C.M., 1984. A Manual of Chemical and Biological Methods for Seawater Analysis. Pergamon Press, London.

Pianosi, F., Beven, K., Freer, J., Hall, J.W., Rougier, J., Stephenson, D.B., Wagener, T., 2016. Sensitivity analysis of environmental models: A systematic review with practical workflow. Environ. Model. Softw. 79, 214-232. doi:10.1016/J.ENVSOFT.2016.02.008

Pitcher, A., Wuchter, C., Siedenberg, K., Schouten, S., Damsté, J.S.S., 2011. Crenarchaeol tracks winter blooms of ammonia-oxidizing Thaumarchaeota in the coastal North Sea. Limnol. Oceanogr. 56, 2308-2318. doi:10.4319/lo.2011.56.6.2308

Powley, H.R., Du, H.H., Lima, A.T., Krom, M.D., Cappellen, P. Van, 2016. Direct Discharges of Domestic Wastewater are a Major Source of Phosphorus and Nitrogen to the Mediterranean Sea. Environ. Sci. Technol. 50, 8722-8730. doi:10.1021/acs.est.6b01742

Rockström, J., Steffen, W., Noone, K., Persson, Å., Chapin, F.S., Lambin, E.F., Lenton, T.M., Scheffer, M., Folke, C., Schellnhuber, H.J., Nykvist, B., de Wit, C.A., Hughes, T., van der Leeuw, S., Rodhe, H., Sörlin, S., Snyder, P.K., Costanza, R., Svedin, U., Falkenmark, M., Karlberg, L., Corell, R.W., Fabry, V.J., Hansen, J., Walker, B., Liverman, D., Richardson, K., Crutzen, P., Foley, J.A., 2009. A safe operating space for humanity. Nature 461, 472-475. doi:10.1038/461472a

Romero, I., Moragues, M., González del Río, J., Hermosilla, Z., Sánchez-Arcilla, A., Sierra, J.P., Mösso, C., 2007. Nutrient Behavior in the Júcar Estuary and Plume. J. Coast. Res. Spec. Issue $48-55$.

Romero, I., Pachés, M., Martínez-Guijarro, R., Ferrer, J., 2013. Glophymed: An index to establish the ecological status for the Water Framework Directive based on phytoplankton in coastal waters. Mar. Pollut. Bull. 75, 218-223. doi:10.1016/j.marpolbul.2013.07.028 
Schaefer, S.C., Hollibaugh, J.T., 2017. Temperature Decouples Ammonium and Nitrite Oxidation in Coastal Waters. Environ. Sci. Technol. 51, 3157-3164. doi:10.1021/acs.est.6b03483

Shinn, M.B., 1941. Colorimetric method for the determination of nitrite. Ind. Eng. Chem. Anal. Ed. 13, 33-35.

Smith, A.F., Fryer, R.J., Webster, L., Berx, B., Taylor, A., Walsham, P., Turrell, W.R., 2014. Setting background nutrient levels for coastal waters with oceanic influences. Estuar. Coast. Shelf Sci. 145, 69-79. doi:10.1016/j.ecss.2014.04.006

Solòrzano, L., 1969. Determination of ammonia in natural waters by the phenol hypoclorite method. Limnol. Oceanogr. 14, 799-801.

Stamou, A.I., Kamizoulis, G., 2008. Estimation of the effect of the degree of sewage treatment on the status of pollution along the coastline of the Mediterranean Sea using broad scale modelling. J. Environ. Manage. 90, 931-939. doi:10.1016/j.jenvman.2008.02.008

Temino-Boes, R., Romero, I., Martinez-Guijarro, R., Pachés, M., 2018. The importance of considering pollution along the coast from heavily modified water bodies under the water framework directive. WIT Trans. Ecol. Environ. 228, 307-316. doi:10.2495/WP180291

Treguer, P., Le Corre, P., 1975. Manuel d'analyse des sels nutritifs dans l'eau de mer, Brest: Université de Bretagne Occidentale.

Umgiesser, G., Melaku Canu, D., Solidoro, C., Ambrose, R., 2003. A finite element ecological model: a first application to the Venice Lagoon. Environ. Model. Softw. 18, 131-145. doi:10.1016/S1364-8152(02)00056-7

Vollenweider, R.., Rinaldi, A., Viviani, R., Todini, E., 1996. Assessment of the state of eutrophication in the Mediterranean Sea. Technical Reports Series No . 106. Athens.

Wang, P.F., Martin, J., Morrison, G., 1999. Water Quality and Eutrophication in Tampa Bay, Florida. Estuar. Coast. Shelf Sci. 49, 1-20. doi:http://dx.doi.org/10.1006/ecss.1999.0490

Wang, Q., Li, S., Jia, P., Qi, C., Ding, F., 2013. A review of surface water quality models. ScientificWorldJournal. 2013, 231768. doi:10.1155/2013/231768 
615 Yool, A., Martin, A.P., Fernández, C., Clark, D.R., 2007. The significance of nitrification for 616 oceanic new production. Nature 447, 999-1002. doi:10.1038/nature05885

617 Zouiten, H., Díaz, C.Á., Gómez, A.G., Cortezón, J.A.R., Alba, J.G., 2013. An advanced tool for 618 eutrophication modeling in coastal lagoons: Application to the Victoria lagoon in the north of Spain. Ecol. Modell. 265, 99-113. doi:10.1016/j.ecolmodel.2013.06.009

620 